\title{
Hydroxysolanascone Glucosides from Flue-cured Tobacco Leaves
}

\author{
Hiroyuki Tazaki, Hisashi Kodama, Takane FujImoRI \\ and Akio OHNISHI \\ Central Research Institute, Japan Tobacco Inc., 6-2 Umegaoka, \\ Midori-ku, Yokohama 227, Japan \\ Received February 12, 1986
}

\begin{abstract}
The structure of 13- and 15-hydroxysolanascone- $\beta$-glucopyranosides, sesquiterpenoid glycosides isolated from flue-cured tobacco leaves, were deduced from the spectral data and by means of the chemical conversion method.
\end{abstract}

Certain sesquiterpenoids were reported as phytoalexins of the Solanaceae, whose structures are closely related to each other. ${ }^{1 \sim 4)} \mathrm{We}$ previously reported the isolation of glycosides of such sesquiterpenoids, including 3-hydroxysolanascone- $\beta$-sophoroside 1 , from the non-volatile components of a tobacco leaf extract. $^{5)}$ In this paper, two newly identified sesquiterpenoid glycosides, tobacco constituents, are presented.

A preliminary experiment on fresh tobacco leaves demonstrated that the enzymic hydrolysis of the non-volatile fraction with $\beta$-glucosidase gave two new sesquiterpenoids. This suggested the presence of their glycosides in tobacco leaves. Therefore, we attempted to obtain sufficient amounts of these glycosides for their structural elucidation from flue-cured tobacco leaves (Nicotiana tabacum L., OCL, $4.7 \mathrm{~kg}$ ) as the starting material.

The isolation procedure is illustrated in Fig. 1. After several steps of extraction and chromatography, with monitoring by means of an enzymic assay with glycosidase, ${ }^{6)}$ a $20 \%$ $\mathrm{MeOH}$ fraction (1127 mg) was obtained as the major glycoside-containing component. This fraction was further separated by HPLC on a YMC S343 column (Fig. 2), and the positive fraction as to the enzymic assay (Fraction 1) was collected and acetylated, and then separated into two compounds, a ( $3 \mathrm{mg})$ and $\mathbf{b}(2 \mathrm{mg})$, on a YMC A314 column.
Compound a 2 was a colorless syrup and the FD-MS data showed a parent of $m / z 564$ and the characteristic fragment peak of $m / z 331$ for a tetraacetylated hexose unit. This observation indicates that a has a tetraacetyl hexopyranose as its sugar moiety, and the molecular weight of the aglycone is 234 . The ${ }^{1} \mathrm{H}-\mathrm{NMR}$ spectrum showed the presence of one methyl $(\delta 1.10)$ joined to a methine, one angular methyl $(\delta 1.33)$, four acetyl methyls, one hydroxymethyl $(\delta 3.53,3.96)$ and ring protons $(\delta 3.6 \sim$ $5.3)$ of the sugar moiety, which were assigned to axial protons on the basis of their coupling constants $(7.8 \sim 9.8 \mathrm{~Hz})$. Compound a was then saponified with $\mathrm{NH}_{3}-\mathrm{MeOH}$ to give the free glycoside, and $\beta$-glucosidase successfully hydrolyzed this free glycoside to liberate the aglycone. The coupling constant of the anomeric proton $(\delta 4.49, J=7.8 \mathrm{~Hz})$ indicated that $\mathbf{a}$ is an acetylated $\beta$-glucoside.

Aglycone 4 has the molecular formula of $\mathrm{C}_{15} \mathrm{H}_{22} \mathrm{O}_{2}$, which was determined from the high resolution mass spectrum (HR-MS). The ${ }^{1} \mathrm{H}-\mathrm{NMR}$ spectral data for the aglycone, summarized in Table I, are similar to those for solanascone (8). However, the signal due to. 15methyl protons of $\mathbf{8}$ is replaced by a signal due to hydroxymethyl protons at $\delta 3.77$ for 4 . Furthermore, the molecular weight (234) of aglycone 4 is well consistent with that of the mono-oxygenated solanascone structure. These results strongly suggested that the struc- 


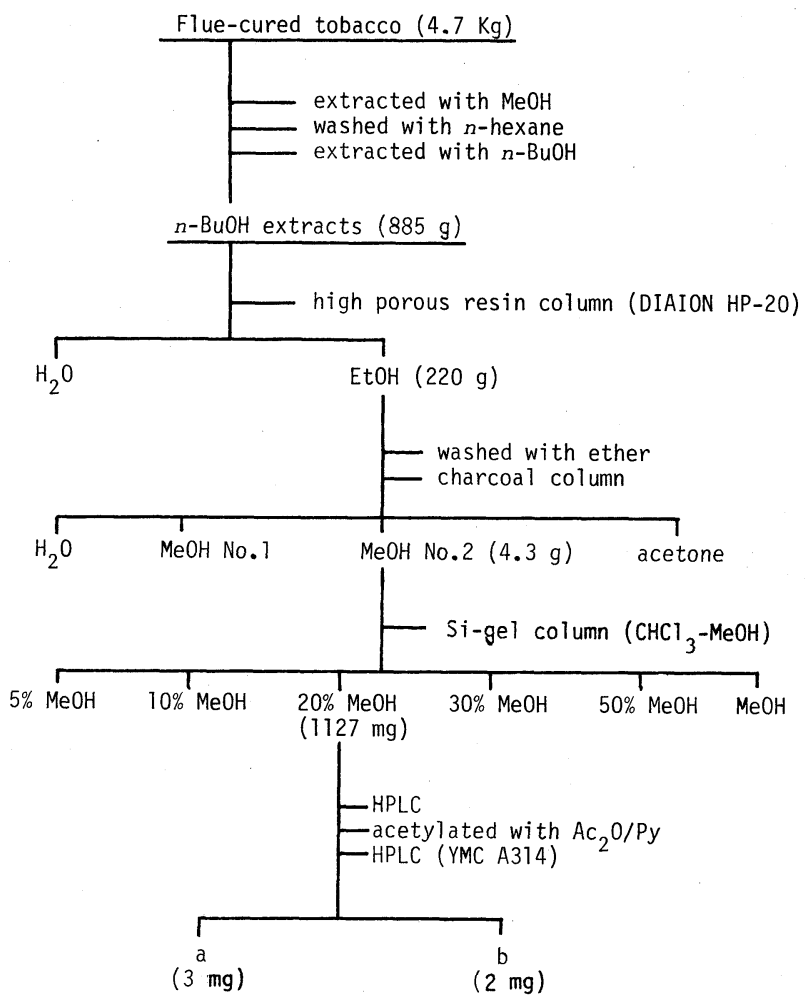

FIG. 1. Isolation Procedure for $\mathbf{a}$ and $\mathbf{b}$.

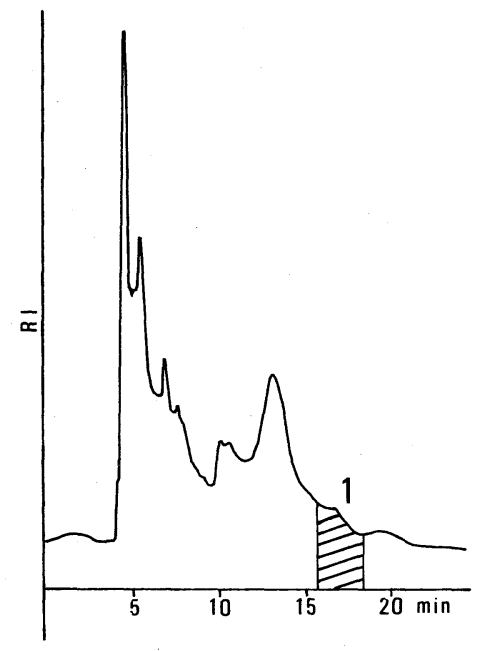

FIG. 2. High Performance Liquid Chromatogram of the $20 \% \mathrm{MeOH}$ Extracted Fraction on a YMC S343 Column Using $\mathrm{MeOH}-\mathrm{H}_{2} \mathrm{O}(1: 1)$ as the Eluant.

ture of the aglycone was 15-hydroxysolanascone (4), which was supported satisfactorily by the 2D-COSY experiment results. The relative configuration of $\mathbf{4}$ was deduced to be as shown in Fig. 4a by the n.O.e experiment results; irradiation at 14-methyl protons enhanced the integrated intensity of the signals of 5-methine, 13-methyl and 15-methylene protons, and irradiation at 13-methyl protons enhanced that of 14-methyl protons. Accordingly, the original glucoside was identified as 15-hydroxysolanascone- $\beta$-glucopyranoside (3).

Compound b 5, a colorless syrup, also showed a parent peak of $\mathrm{m} / z 564$ and the fragment peak $(\mathrm{m} / z$ 331) for a tetraacetylated hexopyranose unit on FD-MS, suggesting that $\mathbf{b}$ is an analogous compound to a, 15-hydroxysolanascone- $\beta$-glucopyranoside tetraacetate (2). The ${ }^{1} \mathrm{H}-\mathrm{NMR}$ spectrum of $\mathbf{b}$ showed the presence of two angular methyls $(\delta 1.01,1.24)$, four acetyl methyls, one hydroxymethyl $(\delta 4.19)$, and ring protons $(\delta 3.6 \sim 5.2)$ of the sugar moiety, which were assigned to axial protons on the basis of their coupling constants $(8.0 \sim 10.1 \mathrm{~Hz})$. Compound b was then 


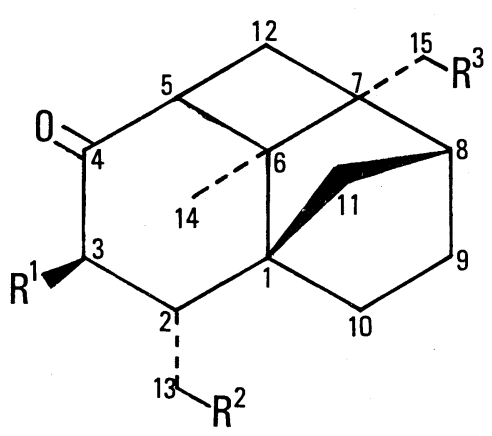

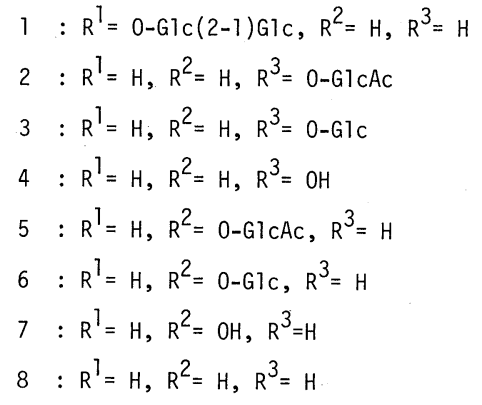

Glc : B-glucopyranosyl

Ac : acetyl

FIG. 3. Structures of Solanascone and Its Derivatives.

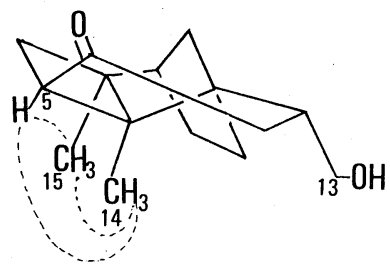

a

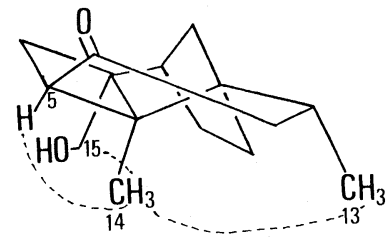

b

FIG. 4. n.O.e. of $\mathbf{4}(\mathbf{a})$ and $\mathbf{7 ( b )}$.

saponified with $\mathrm{NH}_{3}-\mathrm{MeOH}$ to give the free glycoside, and $\beta$-glucosidase successfully liberated the aglycone, $\mathrm{C}_{15} \mathrm{H}_{22} \mathrm{O}_{2}$ (HR-MS), from this free glycoside. These facts and the coupling constant of the anomeric proton $(\delta 4.88$, $J=8.0 \mathrm{~Hz}$ ) indicated that $\mathbf{b}$ is a $\beta$-glucoside. The ${ }^{1} \mathrm{H}-\mathrm{NMR}$ spectral data for aglycone 7 , which are also given in Table I, are similar to those for solanascone 8. However, the signal due to 13-methyl protons of $\mathbf{8}$ is replaced by a signal due to hydroxymethyl protons at $\delta 3.57$ for 7. The molecular weight (234) of aglycone 7 is well consistent with that of the monooxygenated solanascone structure. These findings strongly suggested that the aglycone is 13hydroxysolanascone (7). The 2D-COSY experiment results also supported satisfactorily the structure of 7 . The relative configuration of 7 was deduced to be as shown in Fig. 4 b by the n.O.e experiment results; irradiation at 14methyl protons enhanced the integrated in- tensity of the signals of 15-methyl and 5methine protons, and irradiation at 15-methyl protons enhanced that of 14-methyl and 5methine protons. From these observations the original glucoside was identified as 13-hydroxysolanascone- $\beta$-glucopyranoside (6).

In the previous paper, ${ }^{5,7)}$ we reported the $[2+2]$ type photocyclization of solavetivone or 3-hydroxysolavetivone into solanascone or 3-hydroxysolanascone, respectively. We examined another possibility of the same type of photocyclization from 13-hydroxysolavetivone (9), prepared from an enzymic hydrolyzate of non-volatile components of flue-cured tobacco leaves, into 4 . The photoreaction proceeded and afforded $\mathbf{4}$ as the major product (yield, 72\%) (Fig. 5). This result supported the above mentioned structure of 4 . However, a similar attempt to confirm the proposed structure of 7 was unsuccessful, because 15-hydroxysolavetivone, a precursor of 7 , has not 


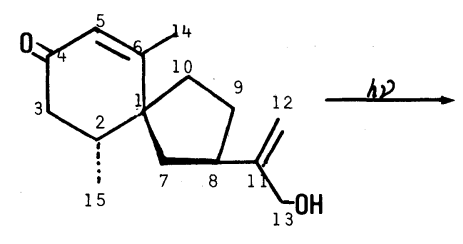

9

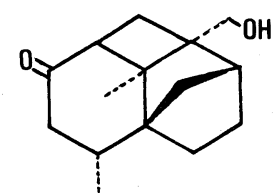

4

FIG. 5. Photocyclization of 9 to 4 .

Table I. ${ }^{1}$ H Chemical Shifts for 2, 4, 5, 7 and 8

\begin{tabular}{|c|c|c|c|c|c|}
\hline \multirow{2}{*}{ H-No. } & \multicolumn{5}{|c|}{ Chemical shifts (ppm) } \\
\hline & 2 & 4 & 5 & 7 & 8 \\
\hline 2 & 2.43 & 2.45 & 2.52 & 2.51 & 2.42 \\
\hline $3 \alpha$ & 2.4 .5 & 2.48 & 2.54 & 2.51 & 2.45 \\
\hline $3 \beta$ & 2.10 & 2.09 & 2.24 & 2.26 & 2.09 \\
\hline 5 & 2.52 & 2.59 & 2.57 & 2.55 & 2.53 \\
\hline 8 & 1.96 & 1.97 & 1.73 & 1.70 & 1.68 \\
\hline 9 & 1.47 & 1.51 & 1.42 & 1.48 & 1.45 \\
\hline $10 \alpha$ & 1.59 & 1.62 & 1.60 & 1.48 & 1.57 \\
\hline $10 \beta$ & 1.30 & 1.31 & 1.31 & 1.36 & 1.25 \\
\hline $11 \alpha$ & 2.04 & 2.05 & 2.10 & 2.09 & 2.02 \\
\hline $11 \beta$ & 1.10 & 1.14 & 1.11 & 1.13 & 1.06 \\
\hline $12 \alpha$ & 2.24 & 2.27 & 1.90 & 1.92 & 1.89 \\
\hline $12 \beta$ & 2.04 & 2.09 & 2.12 & 2.13 & 2.11 \\
\hline 13-Me & 1.10 & 1.13 & $4.19^{a}$ & $3.73^{a}$ & 1.12 \\
\hline 14-Me & 1.33 & 1.36 & 1.24 & 1.26 & 1.30 \\
\hline $15-\mathrm{Me}$ & $3.53,3.96^{a}$ & $3.77^{a}$ & 1.01 & 1.02 & 1.03 \\
\hline $1^{\prime}$ & \multicolumn{2}{|c|}{$4.49(7.8 \mathrm{~Hz})$} & \multicolumn{3}{|c|}{$4.88(8.0 \mathrm{~Hz})$} \\
\hline $2^{\prime}$ & \multicolumn{2}{|c|}{4.99} & \multicolumn{3}{|c|}{4.97} \\
\hline $3^{\prime}$ & \multicolumn{2}{|l|}{5.19} & \multicolumn{3}{|l|}{5.18} \\
\hline $4^{\prime}$ & \multicolumn{2}{|l|}{5.08} & \multicolumn{3}{|l|}{5.07} \\
\hline $5^{\prime}$ & \multicolumn{2}{|l|}{3.67} & \multicolumn{3}{|l|}{3.67} \\
\hline $6^{\prime}$ & \multicolumn{2}{|l|}{$4.14,4.26$} & \multicolumn{3}{|l|}{3.71} \\
\hline
\end{tabular}

${ }^{a}-\mathrm{CH}_{2} \mathrm{O}-$.

been obtained yet.

In conclusion, three hydroxysolanascone glycoside (1, 3 and 6 ) have thus been found in tobacco plants. They are different in the hydroxylation site (C-3, C-13 or C-15) on the carbon skeleton and in the sugar moiety (glucose or sophorose). The possible biosynthetic pathway for these hydroxysolanascone glycosides can be considered to be one of the following: (1) cyclization of hydroxysolavetivone glycosides, (2) cyclization of hydroxysolavetivones followed by glycosidation or (3) hydroxylation of solanascone followed by gly- cosidation. The exact pathway should be clarified through future investigations.

\section{EXPERIMENTAL}

Enzymic hydrolysis. $\beta$-Glucosidase (from sweet almond., P.L. Biochemicals Inc.) showed no activity toward $\alpha$ benzyl glucoside. Glucoside was suspended in $0.1 \mathrm{M}$ sodium acetate buffer $(\mathrm{pH} 5.25)$ and $\beta$-glucosidase was added at $38^{\circ} \mathrm{C}$. After $12 \sim 24 \mathrm{hr}$, the aglycone was extracted from the solution with ether.

Gas chromatography. Analytical GC was performed using a Shimadzu 7A instrument equipped with a F.I. detector and a $20 \mathrm{~m} \times 0.28 \mathrm{~mm}$ i.d. glass capillary column coated with $\mathrm{OV}-101$. The column temperature was programmed at $3^{\circ} \mathrm{C} / \mathrm{min}$ from 150 to $250^{\circ} \mathrm{C}$, and $\mathrm{N}_{2}$ was used as the carrier gas. Preparative GC was performed with a Shimadzu 7A with a T.C. detector and $\mathrm{a}^{*} 1 \mathrm{~m} \times 3.2 \mathrm{~mm}$ i.d. glass column packed with $10 \% \mathrm{OV}-101$ on Chromosorb W (AW) $(80 \sim 180 \mathrm{mesh})$. The column temperature was programmed at $5^{\circ} \mathrm{C} / \mathrm{min}$ from 150 to $250^{\circ} \mathrm{C}$, and $\mathrm{He}$ was used as the carrier gas.

High performance liquid chromatography. HPLC was performed on reversed phase columns, containing YMC A314 $(30 \mathrm{~cm} \times 6.0 \mathrm{~mm}$ i.d. $)$ and YMC S343 $(25 \mathrm{~cm} \times 20$ $\mathrm{mm}$ i.d.), with a $\mathrm{MeOH}-\mathrm{H}_{2} \mathrm{O}$ solvent system using a Hitachi 655 constant flow pump and a Shodex SE-31 differential refractometer for monitoring the column effluent.

Instrumental analysis. Mass spectra were measured with a Hitachi M-80 instrument. GC-MS was performed with the same instrument connected to a Hitachi $655 \mathrm{GC}$ instrument under the same conditions as described above. Optical rotation was measured with a JASCO DIP-181 polarimeter using a $5 \mathrm{~cm}$ long quartz cell at $23^{\circ} \mathrm{C}$. NMR spectra were obtained with a Bruker AM 500 instrument under the same conditions as previously reported. ${ }^{8)}$ Chemical shifts expressed as ppm downfield from TMS as the internal standard.

Preliminary experiment on fresh leaves. Green tobacco leaves ( $N$. tabacum L., MC) were harvested at the Utsu- 
nomiya Experiment Station, JTI, after flowering time. After freeze-drying, $200 \mathrm{~g}$ of the leaves was extracted with $\mathrm{MeOH}$ ( 2 liters), and then the solvent was evaporated. The resultant $\mathrm{MeOH}$ extract was washed successively with $n$ hexane and ether, and then subjected to $n$-BuOH-water partition. The $n-\mathrm{BuOH}$ layer was concentrated and then treated with $\beta$-glucosidase solution. The reaction product was analyzed by GC-MS after extraction with ether.

Isolation of glucoside tetraacetates, $\mathbf{2}$ and $\mathbf{5}$. The isolation procedure, from $4.7 \mathrm{~kg}$ of flue-cured tobacco leaves (N. tabacum L., OCL), is illustrated in Fig. 1.

15-Hydroxysolanascone- $\beta$-glucopyranoside tetraacetate (2). $[\alpha]_{\mathrm{D}}^{23}=-14.0^{\circ}(c=0.08, \mathrm{EtOH}) .{ }^{1} \mathrm{H}-\mathrm{NMR}\left(\mathrm{CDCl}_{3}\right) \delta$ : $1.10(3 \mathrm{H}, \mathrm{d}, J=6.7 \mathrm{~Hz}), 1.10(1 \mathrm{H}, \mathrm{m}), 1.30(1 \mathrm{H}, \mathrm{m}), 1.33$ $(3 \mathrm{H}, \mathrm{s}), 1.47(2 \mathrm{H}, \mathrm{m}), 1.59(1 \mathrm{H}, \mathrm{m}), 1.96(1 \mathrm{H}, \mathrm{m}), 2.04(2 \mathrm{H}$, $\mathrm{m}) ; 2.10(1 \mathrm{H}, \mathrm{m}), 2.24(1 \mathrm{H}, \mathrm{dd}, J=12.0,13.0 \mathrm{~Hz}), 2.43$ (1H, m), 2.45 (1H, m), 2.52 ( $1 \mathrm{H}, \mathrm{dd}, J=6.0,12.0 \mathrm{~Hz}), 3.53$ $(1 \mathrm{H}, \mathrm{d}, J=9.7 \mathrm{~Hz}), 3.67(1 \mathrm{H}, \mathrm{m}, J=2.6,4.5,9.8 \mathrm{~Hz}), 3.96$ $(1 \mathrm{H}, \mathrm{d}, J=9.7 \mathrm{~Hz}), 4.14(1 \mathrm{H}, \mathrm{dd}, J=2.6,12.3 \mathrm{~Hz}), 4.26$ $(1 \mathrm{H}, \mathrm{dd}, J=4.5,12.3 \mathrm{~Hz}), 4.49(1 \mathrm{H}, \mathrm{d}, J=7.8 \mathrm{~Hz}), 4.99$ $(1 \mathrm{H}, \mathrm{dd}, J=7.8,9.4 \mathrm{~Hz}), 5.08(1 \mathrm{H}, \mathrm{dd}, J=9.5,9.8 \mathrm{~Hz})$, $5.19(1 \mathrm{H}, \mathrm{dd}, J=9.4,9.5 \mathrm{~Hz})$. FD-MS $m / z: 564\left(\mathrm{M}^{+}\right), 331$.

13-Hydroxysolanascone- $\beta$-glucopyranoside tetraacetate (5). $[\alpha]_{\mathrm{D}}^{23}=-12.0^{\circ}(c=0.05$, EtOH $) .{ }^{1} \mathrm{H}-\mathrm{NMR}\left(\mathrm{CDCl}_{3}\right) \delta$ : $1.01(3 \mathrm{H}, \mathrm{s}), 1.11(1 \mathrm{H}, \mathrm{m}), 1.24(3 \mathrm{H}, \mathrm{s}), 1.31(1 \mathrm{H}, \mathrm{m}), 1.42$ $(2 \mathrm{H}, \mathrm{m}), 1.60(1 \mathrm{H}, \mathrm{m}), 1.73(1 \mathrm{H}, \mathrm{m}), 1.90(1 \mathrm{H}, \mathrm{m}), 2.10$ $(1 \mathrm{H}, \mathrm{m}), 2.12(1 \mathrm{H}, \mathrm{m}), 2.24(1 \mathrm{H}, \mathrm{m}), 2.52(1 \mathrm{H}, \mathrm{m}), 2.54$ $(1 \mathrm{H}, \mathrm{m}), 2.57(1 \mathrm{H}, \mathrm{m}), 3.67(1 \mathrm{H}$, ddd, $J=2.7,4.7,10.1 \mathrm{~Hz})$, $3.71(2 \mathrm{H}$, ddd, $J=2.7,4.7,12.4 \mathrm{~Hz}), 4.19(2 \mathrm{H}, \mathrm{m}), 4.88$ $(1 \mathrm{H}, \mathrm{d}, J=8.0 \mathrm{~Hz}), 4.97(1 \mathrm{H}, \mathrm{dd}, J=8.0,9.4 \mathrm{~Hz}), 5.07(1 \mathrm{H}$, $\mathrm{dd}, J=9.4,10.1 \mathrm{~Hz}), 5.18(1 \mathrm{H}, \mathrm{dd}, J=9.4,9.4 \mathrm{~Hz})$. FD-MS $m / z: 564\left(\mathbf{M}^{+}\right), 331$.

Saponification and enzymic hydrolysis of 2. Saponification of 2 was performed with saturated $\mathrm{NH}_{3}-\mathrm{MeOH}$ at room temperature for $12 \mathrm{hr}$. The reaction mixture was concentrated by evaporation and then submitted to enzymic hydrolysis to yield 15-hydroxysolanscone (4). $[\alpha]_{\mathrm{D}}^{23}=+13.03^{\circ}(c=0.056, \mathrm{EtOH}) .{ }^{1} \mathrm{H}-\mathrm{NMR}\left(\mathrm{CDCl}_{3}\right) \delta$ : $1.13(3 \mathrm{H}, \mathrm{d}, J=7.1 \mathrm{~Hz}), 1.14(1 \mathrm{H}, \mathrm{m}), 1.31(1 \mathrm{H}, \mathrm{m}), 1.36$ $(3 \mathrm{H}, \mathrm{s}), 1.51(2 \mathrm{H}, \mathrm{m}), 1.62(1 \mathrm{H}, \mathrm{m}), 1.97(1 \mathrm{H}, \mathrm{m}), 2.05(2 \mathrm{H}$, $\mathrm{m}), 2.09(2 \mathrm{H}, \mathrm{m}), 2.27(1 \mathrm{H}, \mathrm{dd}, J=12.1,12.2 \mathrm{~Hz}), 2.45$ $(1 \mathrm{H}, \mathrm{m}), 2.48(1 \mathrm{H}, \mathrm{m}), 2.59(1 \mathrm{H}, \mathrm{dd}, J=6.0,12.1 \mathrm{~Hz}), 3.77$ $(2 \mathrm{H}, \mathrm{s}) .{ }^{13} \mathrm{C}-\mathrm{NMR}\left(\mathrm{CDCl}_{3}\right) \delta: 17.7\left(\mathrm{CH}_{3}\right), 20.7\left(\mathrm{CH}_{3}\right)$, 23.2. $\left(\mathrm{CH}_{2}\right), 26.6\left(\mathrm{CH}_{2}\right), 30.6\left(\mathrm{CH}_{2}\right), 36.8(\mathrm{CH}), 40.2(\mathrm{CH})$, $43.2\left(\mathrm{CH}_{2}\right), 46.5\left(\mathrm{CH}_{2}\right), 49.4(\mathrm{CH}), 50.3(\mathrm{C}), 50.7(\mathrm{C})$, $51.1(\mathrm{C}), 63.6\left(\mathrm{CH}_{2}\right), 213.6(\mathrm{C})$. EI-MS m/z: $234\left(\mathrm{M}^{+}\right)$, 206, 178, 137, 91. HR-MS $m / z$ : 234.1639; calcd. 234.1619 for $\mathrm{C}_{15} \mathrm{H}_{22} \mathrm{O}_{2}$.
Saponification and enzymic hydrolysis of 5. Saponification of 5 was performed with saturated $\mathrm{NH}_{3}-\mathrm{MeOH}$ at room temperature for $12 \mathrm{hr}$. The reaction mixture was concentrated and then submitted to enzymic hydrolysis to yield 13-hydroxysolanascone $(7) .[\alpha]_{\mathrm{D}}^{23}=+6.84^{\circ}(c=0.05$, EtOH). ${ }^{1} \mathrm{H}-\mathrm{NMR}\left(\mathrm{CDCl}_{3}\right) \delta: 1.02(3 \mathrm{H}, \mathrm{s}), 1.13(1 \mathrm{H}, \mathrm{m}$, $J=12.5 \mathrm{~Hz}), 1.26(3 \mathrm{H}, \mathrm{s}), 1.36(1 \mathrm{H}, \mathrm{m}), 1.48(3 \mathrm{H}, \mathrm{m}), 1.70$ (1H, br. s), $1.92(1 \mathrm{H}, \mathrm{dd}, J=11.9,13.2 \mathrm{~Hz}), 2.09(1 \mathrm{H}, \mathrm{m})$, $2.13(1 \mathrm{H}, \mathrm{dd}, J=6.0,13.2 \mathrm{~Hz}), 2.26(1 \mathrm{H}, \mathrm{dd}, J=11.9$, $16.8 \mathrm{~Hz}), 2.51(2 \mathrm{H}, \mathrm{m}), 2.55(1 \mathrm{H}, \mathrm{m}), 3.73(2 \mathrm{H}, \mathrm{m})$. EI-MS $m / z: 234\left(\mathrm{M}^{+}\right), 203,176,133,91$. HR-MS $m / z: 234.1594$; calcd. 234.1619 for $\mathrm{C}_{15} \mathrm{H}_{22} \mathrm{O}_{2}$.

13-Hydroxysolavetivone (9). By means of the method of Anderson et al., ${ }^{9)}$ and subsequent purification by preparative GC, 9 was obtained as a colorless oil from the same fraction of the flue-cured tobacco leaves. The ${ }^{1} \mathrm{H}$ and ${ }^{13} \mathrm{C}$-NMR spectral data were identical with those previously reported. ${ }^{9)}$

Photocyclization of $\mathbf{9}$. Ten $\mathrm{mg}$ of $\mathbf{9}$ was dissolved in $\mathrm{MeOH}(10 \mathrm{ml})$ and then irradiated with sunlight at $25^{\circ} \mathrm{C}$ for $5 \mathrm{hr}$. The reaction mixture was concentrated by evaporation and then the major product was purified by silicagel column chromatography with $n$-hexane-EtOAc $(7: 3)$ as the effluent. Yield, $7.2 \mathrm{mg}(72 \%) .[\alpha]_{\mathrm{D}}^{23}=+15.75^{\circ}(c=$ $0.24, \mathrm{EtOH})$. The ${ }^{1} \mathrm{H}$ - and ${ }^{13} \mathrm{C}-\mathrm{NMR}$ for and MS data for this product were completely identical to those 4 .

\section{REFERENCES}

1) R. Uegaki, T. Fujimori, S. Kubo and K. Kato, Phytochemistry, 24, 2445 (1985).

2) R. S. Burden, P. M. Rowell, J. A. Bailey, R. S. T. Loeffler, M. S. Kemp and C. A. Brown, Phytochemistry, 24, 2191 (1985).

3) D. G. Watson, D. S. Rycroft, I. M. Freer and C. J. W. Broots, Phytochemistry, 24, 2195 (1985).

4) A. Fuchs, W. Slobbe, P. C. Mol and M. A. Posthums, Phytochemistry, 22, 1197 (1983).

5) H. Kodama, T. Fujimori and K. Kato, Agric. Biol. Chem., 49, 2537 (1985).

6) H. Kodama, T. Fujimori and K. Kato, Phytochemistry, 23, 583 (1984).

7) T. Fujimori, R. Kasuga, H. Kaneko, S. Sakamura, M. Noguchi, A. Furusaki, N. Hashiba and T. Matsumoto, J. Chem. Soc., Chem. Commun., 1978, 563.

8) H. Kodama, T. Fujimori and K. Kato, Agric. Biol. Chem., 48, 3131 (1984).

9) R. C. Anderson and D. M. Gunn, J. Chem. Soc., Chem. Commun., 1977, 27. 